\title{
Supplementation of Soy Based Feed with Linseed and its Effects on Growth and Fatty Acid Profile in Grass Carp (Ctenopharyngodon idella)
}

\author{
Shafaq Fatima ${ }^{1, *}$, Farkhanda Manzoor ${ }^{1}$, Humaira Amman', Zakia Kanwal ${ }^{1}$, Asma Latif ${ }^{1}$, \\ Zeeshan Ali ${ }^{2}$, Hamid Iqbal Gondal ${ }^{2}$, Sumera Sajjad ${ }^{1}$ and Raja Shahnawaz Janjua ${ }^{3}$ \\ ${ }^{1}$ Department of Zoology, Lahore College for Women University, Lahore \\ ${ }^{2}$ Pakistan Council of Scientific and Industrial Research, Lahore \\ ${ }^{3}$ SoyPak, Pvt. Ltd.
}

\begin{abstract}
A B S T R A C T
Linseed is an economically important plant source of n-3 polyunsaturated alpha-linolenic acid (ALA) which can be used as supplemental dietary lipid in fish feed particularly carps. In developing countries where fish oil is not an ingredient of fish feed due to its high cost, the addition of economical plant oils rich in n-3 PUFA in fish diet can remarkably improve its quality. The present study evaluated the effect of the addition of linseed in fish feed on growth and fatty acids profile in grass carp (Ctenopharyngodon idella); an important commercial carp in Asia. The present study investigated the effects of three different diets (A, 5\% linseed flour; B, $5 \%$ LO; C, $2.5 \%$ linseed flour $+2.5 \%$ LO) on growth and fatty acids profile $\left(\mathrm{C}_{12: 0}-\mathrm{C}_{22: 6}\right)$ in grass carp (age $=12$ months). The trial continued for 31 days at ambient temperature. The control group was fed with soybean based commercial diet. No significant effect of diet A and $\mathrm{C}$ was observed on fish growth and profile of n-3 and n-6 PUFA in total liver lipids. However, the treatment group fed with diet B showed a significant increase in K $(1.75 \pm 0.14 \%)$, FCR (0.97) and HSI $(0.62 \pm$ $0.1 \%)$ as compared to those in the control group. A high profile of DHA $\left(\mathrm{C}_{22.6}\right)$ was observed in total liver lipids of fish in all three treatments groups (A: $0.31 \%, \mathrm{~B}: 0.41 \%, \mathrm{C}: 0.40 \%)$ in comparison to the control group where DHA was not observed in the fatty acids profile. Similarly, high profiles of EPA $\left(\mathrm{C}_{20.5}\right)$ were observed in all three treatment groups (A: $0.56 \%$, B: $1.64 \%, \mathrm{C}: 1.35 \%$ ) as compared to those in control group. Therefore, the present study indicates that linseed can be a suitable source of n-3 and n-6 PUFA in carp feed, improving the condition and flesh quality of fish.
\end{abstract}

Article Information
Received 24 January 2019
Revised 22 May 2020
Accepted 18 August 2020
Available online 16 July 2021
Authors' Contribution
SF, FM,HA, ZK, AL and SS designed
and executed the study and analysed
the data. ZA and HIG helped in
performing fatty acids analysis while
RSNJ provided technical assistance in
writing the manuscript.
Key words
Linseed, Grass carp, $\alpha$-linolenic acid,
Growth, Fatty acids.

\section{INTRODUCTION}

S ustainable plant based aquafeeds or its supplementation has been an important area of aquaculture research. The global aquafeed industry currently relies mainly upon fish meal, the industry has been continuously looking for a fish feed formulation which is cost effective and have no harmful effects on growth and health of the fish (Hunters and Roberts, 2000). Health conscious consumers desire for high levels of EPA and DHA in their diet therefore maintaining the high level of these PUFAs in fish meat has always been major interest of industry (Schmidt et al., 2005). Fish meal has the highest level of EPA and DHA as compared to plant based feed. Due to high cost and low production of fish meal in developing Asian countries and sustainability issue, aquaculture feed manufacturing industry depend mostly upon plant protein and lipids sources particularly, soybean meal.

A number of studies have investigated the cost and quality benefits of replacing fish oil by $\mathrm{C} 18(\alpha$-linolenic

\footnotetext{
Corresponding author: shafaq.fatima@y7mail.com 0030-9923/2021/0005-1785 \$9.00/0

Copyright 2021 Zoological Society of Pakistan
}

acid) rich vegetable oils such as soybean, linseed and palm oil in many freshwater species. Linseed oil (LO) is the most distinct among all plant oils due to the highest proportion of ALA which can be converted to EPA and DHA by fresh water fish species. Using LO in aquafeed has certain limitations such as its oxidation (Boran et al., 2006). This problem can be resolved by the addition of antioxidants such as vitamin E and tert-butyl hydroxytoluene (BHT) which reduce lipid peroxidation (Chaiyapechara et al., 2003; Lukaszewicz et al., 2004).

Various studies have reported no negative effect of LO substituted diet on growth in different fish species including Atlantic salmon (Salmo salar; Menoyo et al., 2005), rainbow trout (Oncorhynchus mykiss; Turchini and

\footnotetext{
Abbreviations

ALA, alpha-linolenic acid; BHT, butylated hydroxytoluene; DHA, decosahexanoic acid; EPA, eicosapentanoic acid; FCR, feed conversion ratio; HIS, hepatosomatic index; K, condition factor; n-3, omega-3; n-6, omega-6; NFE, nitrogen free extract; LA, linoleic acid; LO, linseed oil; PUFA, polyunsaturated fatty acids; SBM, soybean meal; SGR, specific growth rate; \%WG, percentage weight gain.
} 
Francis, 2009), tilapia (Oreochromis niloticus; Karapanagiotidis et al., 2007), seabream (Pagrus pagrus; Piedecausa et al., 2007), Senegalese sole (Benítez-Dorta et al., 2013), Murray cod (Maccullochella peelii; Francis et al., 2006), rohu (Labeo rohita; Latif et al., 2008) and GIFT tilapia (Oreochromis niloticus; Li et al., 2016). However, the addition of vegetable oils results in increasing the levels of 18:3n-3, 18:2n-6 and 18:1n-9 PUFAs and decreasing levels of EPA and DHA in European seabass (Dicentrarchus labrax) (Mourente and Bell, 2006), rainbow trout (Bell et al., 2002; Masiha et al., 2013) and tilapia (Peng et al., 2016).

Soybean has been widely used as rich plant protein source in aquaculture feeds that supports healthy and efficient fish growth. The cost of soybean mean (SBM) is significantly less (344 USD/MT) than most animal sourced aquaculture feed components (Fishmeal: 1475 USD/ MT) thus maintaining the sustainability in aquaculture operations. However, alpha linolenic acid (ALA) content in soybean is $6.8 \%$ as compared to distinctively high proportion of $53.3 \%$ in LO (NRC, 1993). The deficiency of ALA in SBM can be improved through the addition of linseed meal or LO, improving it as a better plant source aquaculture feed component both in proportion of protein and omega-3 fatty acids.

Linseed is cultivated all over the world. The highest areas of linseed production (94\%) in the world are in Asia, Europe and America, cultivating 49.25\%, 22.57\% and $22.42 \%$, respectively. The average yield ranges from 242 $\mathrm{kg} / \mathrm{ha}$ (Belarus) to $3918 \mathrm{~kg} / \mathrm{ha}$ (Sweden) (Popovic et al., 2016). Therefore, it is an easily available commodity for partial supplementation of aquaculture feed at a cheaper price ( $400 \mathrm{USD} / \mathrm{MT})$ and easy market access.

Considering the above mentioned significance of linseed in improvement of EPA profile and DHA in fish, the present study investigated the effects of addition of the linseed meal and LO in soy based fish feed in grass carp. The main objective of this study was to improve the profile of ALA in SBM by supplementation of linseed to enhance its significance in the local aquaculture feed market. Grass carp was selected as an animal model due to its importance in the major carp aquaculture industry. Global production of this specie was recorded as 55,37,793 tonnes (FAO, 2016) and considered as a major commodity in the Asian aquaculture industry particularly in China. Therefore, it is important to study the effect of linseed supplementation in this species for the purpose of improving growth and flesh quality especially for the Asian region.

\section{MATERIALS AND METHODS}

\section{Growth experiment}

The present study was conducted after the approval of animal ethical committee of Department of Zoology, Lahore College for Women University (LCWU) (RERC/ ZOO/2016-28, 30). A total of 64 fish (body weight: $82.22 \pm$ $10.00 \mathrm{~g}$, body length: $17.37 \pm 0.55 \mathrm{~cm})$ were obtained from a commercial fish farm (Himalaya Hatchery, Sheikhupura) and transferred to aquaria $(92 \mathrm{~cm} \times 44 \mathrm{~cm} \times 42 \mathrm{~cm})$ located at the Aquaculture Facility, Lahore College For Women University on April 4, 2017. Fish were divided into one control $(n=16)$ and three treatment groups $(n=16$ in each group). Each group had two replicates. Water quality parameters were maintained at $\mathrm{pH}$ 6.8- 7.2, chlorine $<$ $0.02 \mathrm{mg} / \mathrm{L}$, total ammonia $<2 \mathrm{mg} / \mathrm{L}$, nitrite $<1 \mathrm{mg} / \mathrm{L}$, nitrate $<80 \mathrm{mg} / \mathrm{L}$. Fish were fed at the rate of $2 \%$ of their body weight three times a day. Fish were acclimatized for three days under ambient conditions. Trials continued for a period of 36 days (April 5 - May 5, 2017).

\section{Experimental diets}

Fish in the control group were fed with soy based commercial feed (Oryza Organics, Pakistan). Treatment diets were prepared by supplementing commercial feed with 5\% linseed flour (Diet A), 5\% linseed oil (Diet B), and combination diet $(2.5 \%$ linseed flour + $2.5 \%$ linseed oil) (Diet C). Vitamin E (7.5 g/kg) and butylated hydroxytoluene (BHT) $(12.5 \mathrm{~g} / \mathrm{kg})$ were used as antioxidants.

\section{Calculations}

Total body length $( \pm 1 \mathrm{~mm})$ and total body weight $( \pm 1$ g) of fish were measured after every week. \%WG, K, SGR and FCR were measured each week by using the following formulae:

$$
\begin{aligned}
& \% \mathrm{WG}=100[(\mathrm{Wf}-\mathrm{Wi}) / \mathrm{Wi}] \\
& \mathrm{K}=\mathrm{W} /(\mathrm{L})^{3} \times 100 \\
& \mathrm{SGR}(\% / \text { day })=100 \times[(\operatorname{lnW} 1-\ln \mathrm{W} 0) / \mathrm{t}] \\
& \mathrm{FCR}=\text { food consumed }(\mathrm{g}) / \text { weight gain }(\mathrm{g})
\end{aligned}
$$

All fish were killed at final sampling using an overdose of anesthetic through means of transfer into a 50-L tank containing $20 \mathrm{ml} / 1$ of clove oil. Liver weight $( \pm 1 \mathrm{~g})$ was measured to calculate HSI using the following formula:

HSI $=[$ liver weight $(\mathrm{g}) /$ total body weight $(\mathrm{g})] \times 100$

\section{Proximate analysis}

Proximate analysis of prepared feed and soy based commercial feed was performed by utilizing the lab facility of Applied Chemistry Research Center, PCSIR Lahore. The level of moisture in the diets was estimated by drying at $100 \pm 2{ }^{\circ} \mathrm{C}$ until their weight was constant for 24 h. The level of crude protein $(\mathrm{N} \times 6.25)$ was determined by using the Kjeldahl method. The total ash in the diets was assessed after the combustion at $550 \pm 25^{\circ} \mathrm{C}$ over-night 
and crude fat from the diets samples was extracted with a Soxhlet extractor. Feed ingredients and composition of control and experimental diet is given in Table I.

Table I.- Ingredient (\%) and proximate composition (\% dry matter) of the control and experimental diets.

\begin{tabular}{|c|c|c|c|c|}
\hline \multirow[t]{2}{*}{ Ingredients (\%) } & \multirow{2}{*}{$\begin{array}{l}\text { Control* } \\
\text { SBM }\end{array}$} & \multicolumn{3}{|c|}{ Treatments* } \\
\hline & & $\begin{array}{l}\text { Linseed } \\
\text { flour }\end{array}$ & \multicolumn{2}{|c|}{$\begin{array}{c}\text { Linseed } \\
\text { oil }\end{array}$} \\
\hline Ground wheat & 14.30 & 8.60 & \multicolumn{2}{|c|}{8.60} \\
\hline Soybean meal & 25.40 & 40.00 & \multicolumn{2}{|c|}{20.00} \\
\hline Linseed oil & _ & 4.00 & \multicolumn{2}{|c|}{8.00} \\
\hline Wheat starch & 2.00 & 2.00 & \multicolumn{2}{|c|}{2.00} \\
\hline $\begin{array}{l}\text { Carboxy methyl } \\
\text { cellulose }\end{array}$ & 28.09 & 10 & \multicolumn{2}{|c|}{10} \\
\hline Mineral premix ${ }^{\mathrm{a}}$ & 0.30 & 1.50 & \multicolumn{2}{|c|}{1.50} \\
\hline Vitamin premix ${ }^{\mathrm{b}}$ & 0.30 & 2.00 & \multicolumn{2}{|c|}{2.00} \\
\hline Soybean hulls & 15.40 & - & \multicolumn{2}{|c|}{-} \\
\hline $\begin{array}{l}\text { Proximate } \\
\text { composition (\%) }\end{array}$ & Control & T 1 & T 2 & T 3 \\
\hline Crude protein & 30.00 & 30.15 & 30.20 & 30.25 \\
\hline Crude lipids & 5.50 & 13.10 & 17.65 & 15.75 \\
\hline Crude fiber & 6.50 & 2.91 & 2.00 & 2.74 \\
\hline Ash & 7.80 & 5.00 & 5.00 & 4.00 \\
\hline Moisture & 10.00 & 9.60 & 8.00 & 9.40 \\
\hline $\mathrm{NFE}^{\mathrm{c}}$ & 40.20 & 39.24 & 37.51 & 37.86 \\
\hline
\end{tabular}

*Each treatment and control had two replicates. $\mathrm{n}$ was 16 in each group. a, contains ( $\mathrm{mg} / \mathrm{Kg}$ food): $\mathrm{Mg}, \mathrm{Zn}, \mathrm{Fe}, \mathrm{Cu}, \mathrm{CO}$ and I; b, contains $(\mathrm{mg} / \mathrm{Kg}$ food) $\mathrm{E}, \mathrm{K}$, niacin, thiamine, riboflavin, folacin, pyridoxine and biotin; c, NFE: nitrogen free extract calculated by difference (100-moisture-ashcrude protein-crude lipid-crude fibers).

\section{Estimation of fatty acid}

Total liver lipids were extracted according to Bligh and Dyer (1959) method. Fatty acids profile $\left(\mathrm{C}_{12: 0}-\mathrm{C}_{22: 6}\right)$ in total liver lipids were determined by Gas Chromatography Flame Ionization Detector (GC-FID).

\section{Statistical analysis}

Statistical analysis was performed following Peng et al. (2017) procedure. One-way ANOVA was performed to analyze the variance between weekly values of control and each treatment group. Paired sample t-test was carried out to compare the weekly values of the control group with those of the treatment groups. $\mathrm{P}<0.05$ indicated significant differences between means.

\section{RESULTS}

Weekly mean values of $\mathrm{K}$ (condition factor) in control group were found to be insignificant at $(\mathrm{P}>0.05)$ different throughout the trial $\left(\mathrm{F}_{3,33}=1.82\right)$ (Fig. 1). Similarly, no significant difference $(\mathrm{P}>0.05)$ was observed between weekly means of $\mathrm{K}$ in treatment $\mathrm{A}\left(\mathrm{F}_{3,33}=0.62\right)$. On the other hand, a significant difference $(\mathrm{P}<0.05)$ was observed in weekly mean values of $\mathrm{K}$ in both treatment $\mathrm{B}\left(\mathrm{F}_{3,34}=\right.$ 4.43) and $\mathrm{C}\left(\mathrm{F}_{3,31}=3.41\right)$.

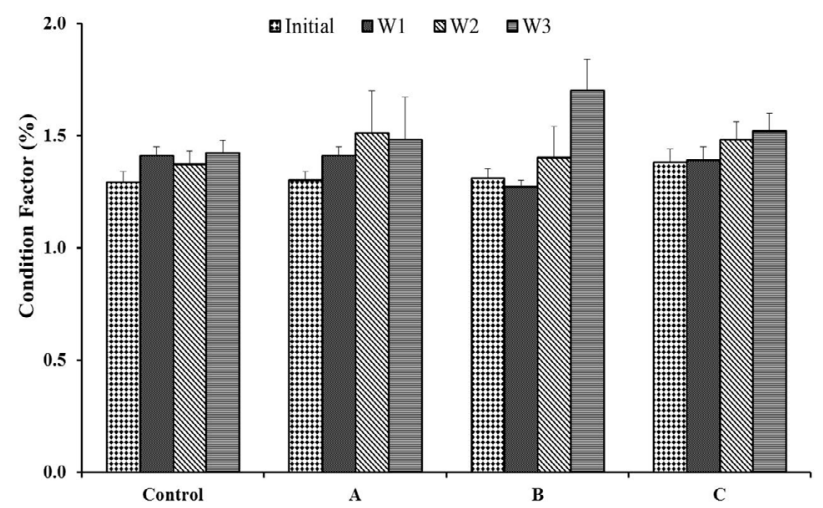

Fig. 1. Weekly (Mean \pm SE) variations in condition factor in control and treatment groups of grass carp (Ctenopharyngodon idella). Diet of treatment group A, B and C contained $5 \%$ of linseed flour, $5 \%$ linseed oil, combination $(2.5 \%$ linseed flour $+2.5 \%$ linseed oil), respectively. Trial continued for 36 days (April 5 May 5, 2017). Control group was fed with soybean feed. Initial: Pre-treatment value, $\mathrm{W} 1$ : first week post-treatment, W2: second week post-treatment, W3: third week posttreatment

Table II.- Weekly (mean \pm SE) variations in specific growth rate $(\%)$ and feed conversion ratio in control and treatment groups of of grass carp (Ctenopharyngodon idella) fed with three different diets (A, 5\% linseed flour; B, 5 \% linseed oil; C, $2.5 \%$ linseed flour $+2.5 \%$ linseed oil) over the period of 36 days (April 5 - May, 5, 2017). Control group was fed with soybean feed.

\begin{tabular}{|c|c|c|c|c|c|c|c|c|}
\hline \multirow{2}{*}{$\begin{array}{l}\text { Sample } \\
\text { point }\end{array}$} & \multicolumn{4}{|c|}{ Specific growth rate (\%) } & \multicolumn{4}{|c|}{ Feed conversion ratio } \\
\hline & Control & $\mathbf{A}$ & B & $\mathrm{C}$ & Control & $\mathbf{A}$ & B & $\mathbf{C}$ \\
\hline Week 1 & $0.12 \pm 0.01$ & $0.24 \pm 0.01$ & $0.26 \pm 0.01$ & $0.26 \pm 0.01$ & 1.24 & 1.29 & 1.29 & 1.37 \\
\hline Week 2 & $0.18 \pm 0.01$ & $0.23 \pm 0.02$ & $0.21 \pm 0.03$ & $0.22 \pm 0.01$ & 1.28 & 1.35 & 1.26 & 1.25 \\
\hline Week 3 & $0.21 \pm 0.02$ & $0.26 \pm 0.04$ & $0.23 \pm 0.01$ & $0.25 \pm 0.02$ & 1.31 & 1.30 & 1.31 & 1.34 \\
\hline
\end{tabular}


During the final sample point, HSI was found to be $0.59 \pm 0.11 \%, 0.62 \pm 0.1 \%, 0.52 \pm 0.03 \%$ and $0.55 \pm 0.1$ $\%$ in control, treatment $\mathrm{A}, \mathrm{B}$ and $\mathrm{C}$ group, respectively. SGR and FCR in treatment groups were found to be insignificant at $(\mathrm{P}>0.05)$ different from those in the control group (Table II). Levels of $\alpha$-Linolenic acid were found to be higher in control $(4.46 \%)$ in comparison to treatment groups (Table III). Fish in treatment B showed the highest proportion of EPA $\left(\mathrm{C}_{22: 5}\right)(1.64 \%)$ as compared to treatment $\mathrm{A}, \mathrm{C}$ and control group. DHA $\left(\mathrm{C}_{22: 6}\right)$ was observed only in treatments.

Table III.- Comparison of fatty acid profile (\%) in total liver lipids of grass carp (Ctenopharyngodon idella) fed with three different diets (A, 5\% linseed flour; B, $5 \%$ linseed oil; C, $2.5 \%$ linseed flour $+2.5 \%$ linseed oil) over the period of 36 days (April 5 - May, 5, 2017). Control group was fed with soybean feed.

\begin{tabular}{llcccc}
\hline $\begin{array}{l}\text { Carbon } \\
\text { No. }\end{array}$ & Fatty acids & Control & A & B & C \\
\hline C $_{12: 0}$ & Lauric acid & 1.34 & 1.32 & 1.30 & - \\
$\mathrm{C}_{14: 0}$ & Myristic acid & 0.44 & 0.47 & 0.15 & 0.76 \\
$\mathrm{C}_{16: 0}$ & Palmitic acid & 26.10 & 28.79 & 38.69 & 33.66 \\
$\mathrm{C}_{16: 1}$ & Palmitoleic acid & 1.02 & 0.40 & 0.31 & 0.39 \\
$\mathrm{C}_{17: 0}$ & Heptadecanoic acid & - & 0.73 & 1.30 & 0.52 \\
$\mathrm{C}_{18: 0}$ & Stearic acid & 5.49 & 0.91 & 1.20 & 0.50 \\
$\mathrm{C}_{18: 1}$ & Oleic acid & 36.50 & 39.89 & 39.11 & 39.09 \\
$\mathrm{C}_{18: 2}$ & Linoleic acid & 19.87 & 24.85 & 12.71 & 17.23 \\
$\mathrm{C}_{18: 3}$ & $\alpha$-Linolenic acid & 4.46 & 0.57 & 1.07 & 1.73 \\
$\mathrm{C}_{18: 3}$ & $\beta$-Linolenic acid & 2.15 & 0.36 & - & 2.31 \\
$\mathrm{C}_{20: 0}$ & Arachidic acid & 1.10 & 0.32 & 0.35 & 0.73 \\
$\mathrm{C}_{20: 1}$ & Condolic acid & 0.74 & 0.33 & 1.13 & 1.22 \\
$\mathrm{C}_{20: 2}$ & Eicosadionic acid & - & - & 0.24 & - \\
$\mathrm{C}_{20: 3}$ & Eicosatrionic acid & - & - & - & - \\
$\mathrm{C}_{20: 5}$ & Eicosapentanoic acid & 0.79 & 0.56 & 1.64 & 1.35 \\
$\mathrm{C}_{22: 0}$ & Decosanoic acid & - & 0.20 & 0.22 & 0.23 \\
$\mathrm{C}_{22: 6}$ & Decosahexanoic acid & - & 0.31 & 0.41 & 0.40 \\
\hline
\end{tabular}

\section{DISCUSSION}

In the present study, supplementation of linseed (flour and oil) in fish feed in treatments group showed higher levels of EPA and DHA in comparison to nonsupplemented soy based feed in control group. The highest levels of C16:0, C18:1n and n3 LC-PUFAs, EPA (20:5n$3)$, and DHA (22:6n-3) were observed in the LO group. This finding was in agreement with previous studies on common carp (Cyprinus carpio; Zhelyazkov et al., 2014; Zupan et al., 2016), rainbow trout (Masiha et al., 2013),
Senegalese sole (Benítez et al., 2013), Nile tilapia (Omolo et al., 2017) and juvenile turbot (Peng et al., 2017). This finding was in contrast with silver barb fingerlings (Nayak et al., 2017). In the present study it was observed that dietary total proportion of LA and ALA was higher in the control group but lower in the treatment groups. However, higher levels of EPA and DHA levels found in treatment groups may be attributable to enzymes $\Delta 6$ and $\Delta 5$ fatty acyl desaturase (FAD) and elongase, involved in the biosynthesis of LC-PUFAs (EPA and DHA) from the catalysis of the $\mathrm{C} 18$ substrates LA/ALA. In fish, both LA and ALA are considered essential due to their incapability to biosynthesized these acids de novo. It is well known that freshwater fish species have a high dietary requirement for n-3 and n-6 fatty acids in comparison to marine fish species, predominantly in the form of $\alpha$-linolenic and linoleic acids (Turchini and Francis, 2009). In present study, high DHA content in liver samples of treatment groups indicated the conversion of some of ALA into n-3 LC PUFA. It suggests that carp has a capacity to desaturate and elongate ALA to EPA and DHA. Similar observation has also been reported in other freshwater fishes, tilapia (Li et al., 2016), common carp (Zupan et al., 2016) and trout (Turchini and Francis, 2009).

Although a superior profile of EPA and DHA were observed in the LO group however, higher crude lipids were also observed. Lipid deposition in fish fed with higher lipids proportion in their diet has been observed in a number of species including, common carp (Zupan et al., 2016), rainbow trout (Masiha et al., 2013), brown trout (Salmo trutta) (Arslan et al., 2012), Senegalese sole (Reis et al., 2014) and turbot (Scophthalmus maximus) (Mourente et al., 2005). The health benefits of a diet rich in EPA and DHA are well documented in fetal development, Alzheimer's disease, diabetes, cardiovascular disease, inflammatory disorders and immune dysfunction (Swanson et al., 2012; Soni et al., 2016; Bechoua et al., 2003; Bell et al., 2004). Adiposity due to the addition of LO in soy based feed can be improved by further adjusting LO according to market requirements. In contrast to the improvement in EPA and DHA profiles in treatment groups, SGR and FCR did not show any increase over the study period. Similar results were observed in juvenile tench (Zakes et al., 2010) and turbot (Altundag et al., 2014; Peng et al., 2017). In contrast to this, previous study on common carp showed significant increase in growth rate by increasing the concentration of linseed oil indicated that concentration of LO influence on the growth performance (Zupan et al., 2016). The SGR results of present study could possibly be due to the short duration of study trials and the concentration of added linseed (flour, oil). The results of the present study do not agree with some reports that by increasing the dietary 
lipid content, the growth of the fish may improve (Pei et al., 2004; El-Marakby, 2006). On the other hand, it has also reported that a high dietary lipid level $(>7 \%)$ could reduce fish growth (Pei et al., 2004; El-Marakby, 2006; Zupan et al., 2016). It could be due to the reduction in feed intake, low ability to digest and absorb high lipid and fatty acid imbalance in the diet. From previous studies it has been noticed that fish are especially sensitive to the quality of feed and the presence of dietary anti-nutritional factors (NRC, 1993). One of the major problems in using the alternative vegetable protein and lipid sources in aquaculture feeds is their palatability that is mainly related to feed taste. Therefore, the determination of feed ingredients is an important condition for evaluation of their potential use in fish nutrition. The results of the present study showed that the use of linseed in experimental fish diets did not result in low growth rates and stunted growth; therefore, it is a suitable feed component for carp.

This study also shows that replacing fish oil with vegetable oils consistently results in major changes in fatty acid profile of fish. In this and previous studies considering n-3 LC-PUFAs such as EPA and DHA is important as these acids are extremely beneficial to human health and the final quality of fish. These fatty acids as well as arachidonic acid (ARA), another essential fatty acid, are normally expected to be found abundantly in fish. However, there is concern that by partially or totally replacing the fish oil in fish diets with vegetable oil, the amount of healthy fatty acids in the fish meat may be reduced and this concern may have more validity in marine fish.

\section{CONCLUSION}

In conclusion, $5 \%$ LO supplementation of commercial extruded soy based feed for carps, increased the profile of EPA and DHA. However, no significant increase in SGR and FCR could be observed in the treatment group which might be related to short duration of trial. The present study showed that the linseed oil could be successfully used as a supplement component for carp feed. Their addition to the extruded feed positively influenced the growth while producing no negative effect on the survival rate of the fish and FCR.

\section{ACKNOWLEDGEMENT}

Authors acknowledge the technical support of Applied Chemistry Research Centre, PCSIR in analysis of fatty acids profile.

\section{Statement of conflict of interest}

The authors declare no conflict of interest.

\section{REFERENCES}

Altundag, M.S., Tiril, S.U. and Ozdemir, A., 2014. Effects of sunflower oil supplementation in diet on growth performance and body fatty acid composition of turbot (Psetta maxima). Aquacult. Int., 22: 597-605. https://doi.org/10.1007/s10499013-9686-x

Arslan, M., Sirkecioglu, N., Bayir, A., Arslan, H. and Aras, M., 2012. The influence of substitution of dietary fish oil with different vegetable oils on performance and fatty acid composition of brown trout (Salmo trutta). Fish. aquat. Sci., 12: 575-583. https://doi.org/10.4194/1303-2712-v12_3_04

Bechoua, S., Dubois, M., Vericel, E., Chapuy, P., Lagarde, M. and Prigent, A.F., 2003. Influence of very low dietary intake of marine oil on some functional aspects of immune cells in healthy elderly people. Br. J. Nutr., 89: 523-531. https:// doi.org/10.1079/BJN2002805

Bell, J.G., Henderson, R.J., Tocher, D.R., McGhee, F., Dick, J.R. and Porter, A., 2002. Substituting fish oil with crude palm oil in the diet of Atlantic salmon (Salmo salar) affects muscle fatty acid composition and hepatic fatty acid metabolism. J. Nutr., 132: 222-230. https://doi.org/10.1093/jn/132.2.222

Benítez-Dorta, V., Caballero, M.J., Izquierdo, M., Manchado, M., Infante, C., Zamorano, M.J. and Montero, D., 2013. Total substitution of fish oil by vegetable oils in Senegalese sole (Solea senegalensis) diets: Effects on fish performance, biochemical composition, and expression of some glucocorticoid receptor-related gene. Fish Physiol. Biochem., 39: 335-349. https://doi.org/10.1007/ s10695-012-9703-4

Bligh, E.G. and Dyer, W.J., 1959. A rapid method of total lipid extraction and purification. Can. J. Biochem. Physiol., 37: 911-917.

Boran, G., Karacam, H. and Boran, B., 2006. Changes in the quality of fish oils due to storage temperature and time. Fd. Chem., 98: 693-698. https://doi. org/10.1016/j.foodchem.2005.06.041

Chaiyapechara, S., Casten, M.T., Hardy, R. and Dong, R.M., 2003. Fish performance, fillet characteristics, and health assessment index of rainbow trout (Onchorhynchus mykiss) fed diets containing adequate and high concentrations of lipid and vitamin E. Aquaculture, 219: 715-738. https://doi. org/10.1016/S0044-8486(03)00025-5

El-Marakby, M., 2006. Effect of dietary sources and levels of lipids on growth performance and feed utilization of fry Nile tilapia, Oreochromis niloticus 
(L.). Fish. aquat. Sci., 1: 117-125. https://doi. org/10.3923/jfas.2006.117.125

FAO, 2016. The state of world fisheries and aquaculture. Contributing to food security and nutrition for all. Food and Agriculture Organization, Rome, pp. 200.

Francis, D.S., Turchini, G.M., Jones, P.L. and de Silva, S.S., 2006. Effects of dietary oil source on growth and fillet fatty acid composition of Murray cod (Maccullochella peelii peelii). Aquaculture, 253: $547-556 . \quad \mathrm{https} / / /$ doi.org/10.1016/j. aquaculture.2005.08.008

Hunter, B.J. and Roberts, D.C.K., 2000. Potential impact of the fat composition of farmed fish on human health. Nutr. Res., 20: 1047-1058. https:// doi.org/10.1016/S0271-5317(00)00181-0

Karapanagiotidis, I.T., Bell, M.V., Little, D.C. and Yakupitiyage, A., 2007. Replacement of dietary fish oils by alpha-linolenic acid-rich oils lowers omega 3 content in tilapia flesh. Lipids, 42: $547-$ 559. https://doi.org/10.1007/s11745-007-3057-1

Latif, K.A., Alam, M.T., Sayeed, M.A., Afzal, H.M., Sultana, S. and Hossain, A.M., 2008. Comparative study on the effects of low cost oil seed cakes and fish meal as dietary protein sources for Labeo rohita (Hamilton) fingerling. J. Zool., 27: 25-30. https:// doi.org/10.3329/ujzru.v27i0.1949

Li, F.J., Lin, X., Lin, S.M., Chen, W.Y. and Guan, Y., 2016. Effects of dietary fish oil substitution with linseed oil on growth, muscle fatty acid and metabolism of tilapia (Oreochromis niloticus). Aquacult. Nutr., 22: 499-508. https://doi.org/10.1111/anu.12270

Lukaszewicz, M., Szopa, J. and Krasowska, A., 2004. Susceptibility of lipids from different flax cultivars to peroxidation and its lowering by added antioxidants. Fd. Chem., 88: 225-231. https://doi. org/10.1016/j.foodchem.2003.12.042

Masiha, A., Ebrahimi, E., Soofiani, M.N. and Kadivar, M., 2013. Effect of dietary vegetable oils on the growth performance and fatty acid composition of fingerlings of Rainbow trout (Oncorhynchus mykiss). Fd. Sci. Tech., 1: 21-29. https://doi. org/10.1186/2193-1801-2-1

Menoyo, D., López-Bote, C.J., Obach, A. and Bautista, J.M., 2005. Effect of dietary fish oil substitution with linseed oil on the performance, tissue fatty acid profile, metabolism, and oxidative stability of Atlantic salmon. J. Anim. Sci., 83: 2853-2862. https://doi.org/10.2527/2005.83122853x

Mourente, G. and Bell, J.G., 2006. Partial replacement of dietary fish oil with blends of vegetable oils (rapeseed, linseed and palm oils) in diets for European sea bass (Dicentrarchus labrax L.) over a long term growth study: effects on muscle and liver fatty acid composition and effectiveness of a fish oil finishing diet. Comp. Biochem. Physiol. B, 14: 389399. https://doi.org/10.1016/j.cbpb.2006.08.012

Mourente, G., Good, J.E. and Bell, J.G., 2005. Partial substitution of fish oil with rapeseed, linseed and olive oils in diets for European sea bass (Dicentrarchus labrax L.): Effects on flesh fatty acids composition, plasma prostaglandins E2 and F2a, immune function and effectiveness of fish oil finishing diet. Aquacult. Nutr., 11: 25-40. https:// doi.org/10.1111/j.1365-2095.2004.00320.x

Nayak, M., Saha, A., Pradhan, A., Samanta, M. and Giri, S.S., 2017. Dietary fish oil replacement by linseed oil: Effect on growth, nutrient utilization, tissue fatty acid composition and desaturase gene expression in silver barb (Puntius gonionotus) fingerlings. Comp. Biochem. Physiol., 205: 1-12. https://doi.org/10.1016/j.cbpb.2016.11.009

NRC, 1993. Nutrient requirements of fish. National Research Council, National Academy Press, Washington, DC, USA.

Omolo, K.M., Onyango, A., Magoma, G., Munguti, J. and Ogila, K., 2017. Dietary effect of varying linseed oil compositions on growth response, survival and polyunsaturated fatty acid levels in Tilapia (Oreochromis niloticus). Fish. Aquacult., 9: 31-41. https://doi.org/10.5897/IJFA2017.0621

Pei, Z., Xie, S., Lei, W., Zhu, X. and Yang, Y., 2004. Comparative study on the effect of dietary lipid level on growth and feed utilization for Gibel carp (Carassius auratus Gibelio) and Chinese longsnout catfish (Leoiocassis longirostris Günther). Aquacult. Nutr., 10: 209-216. https://doi. org/10.1111/j.1365-2095.2004.00291.X

Peng, M., Xua, W., Tana, P., Maia, K.D.J., Zhoua, H., Zhanga, Y., Nianb, R., Macqc, B. and Aia, Q., 2017. Effect of dietary fatty acid composition on growth, fatty acids composition and hepatic lipid metabolism in juvenile turbot (Scophthalmus maximus L.) fed diets with required n3 LCPUFAs. Aquaculture, 479: 591-600. https://doi. org/10.1016/j.aquaculture.2017.06.032

Peng, X., Li, F. and Lin, S., 2016. Effects of total replacement of fish oil on growth performance, lipid metabolism and antioxidant capacity in tilapia (Oreochromis niloticus). Auacult. Int., 24: 145-156. https://doi.org/10.1007/s10499-015-9914-7

Piedecausa, M.A., Mazón, M.J., García, G.B. and Hernández, M.D., 2007. Effects of total replacement of fish oil by vegetable oils in the diets of sharpsnout seabream (Diplodus 
puntazzo). Aquaculture, 263: 211-219. https://doi. org/10.1016/j.aquaculture.2006.09.039

Popovic, V., Sikora, V., Tatić, M., Filipović, V., Terzić, D., Janjić, S. and BrdarJokanović, M., 2016. Analysis of production of linseed (Linum usitatissimum L.) in the world. $20^{\text {th }}$ International Eco-Conference, 9 $^{\text {th }}$ International Eco-Conference on Safe Food, pp. 119-127

Reis, B., Cabral, M.E., Telmo, J.R.F., Cunha, C.M., Beatriz, M.P.P.O., Cunha, M.L. and Luísa, M.P.V., 2014. Long-term feeding of vegetable oils to Senegalese sole until market size: Effects on growth and flesh quality. Recovery of fatty acid profiles by a fish oil finishing diet. Aquaculture, 434: 425-433. https://doi.org/10.1016/j.aquaculture.2014.09.002

Schmidt, E.B., Arnesen, H., de Caterina, R., Rasmussen, L.H. and Kristensen, S.D., 2005. Marine n-3 polyunsaturated fatty acids and coronary heart disease. Part I. Background, epidemiology, animal data, effects on risk factors and safety. Thrombosis Res., 115: 163-170. https://doi.org/10.1016/j. thromres.2004.09.006

Soni, P.R., Katoch, M., Kumar, A. and Verma, P., 2016. Flaxseed - composition and its health benefits. Res. Environ. Life Sci., 9: 310-316.
Swanson, D., Block, R. and Mousa, S.A., 2012. Omega-3 fatty acids EPA and DHA: Health benefits throughout life. Adv. Nutr., 3: 1-7. https:// doi.org/10.3945/an.111.000893

Turchini, G.M. and Francis, D.S., 2009. Fatty acid metabolism (desaturation, elongation and $\beta$-oxidation) in rainbow trout fed fish oil- or linseed oil-based diets. Br. J. Nutr., 102: 69-81. https://doi. org/10.1017/S0007114508137874

Zakes, Z., Jankowska, B., Jarmołowicz, S., Zmijewski, T., Partyka, K. and Zakes, D.K., 2010. Effects of different dietary fatty acids profiles on the growth performance and body composition of juvenile tench (Tinca tinca L.). Fish Biol. Fish., 20: 389401. https://doi.org/10.1007/s11160-009-9146-x

Zhelyazkov, G., Staykov, Y. and Nikolov, G., 2014. Effect of linseed and sunflower oil supplementation in the diet on the growth performance in carp (Cyprinus carpio L.), cultivated in a recirculating system. Res. Environ. Life Sci., 6: 263-266.

Zupan, B., Jubojevic, D., Pelic, M., Cirkovic, M., Oordevic, O., Bogut, I. and Res, V.S., 2016. Common carp response to the different concentration of linseed oil in diet. Slov. Vet. Res., 53: 19-28. 